\title{
Impact of Land Use Changes in Florida Mega Region: Study of FDOT (D-5) from Year 2007-2015
}

\author{
Prashant Singh ${ }^{*}$, Md. Ahsanul Islam² \\ ${ }^{1}$ Department of Civil \& Coastal Engineering, University of Florida, Gainesville, FL, USA \\ ${ }^{2}$ Parsons Corporation, East Hartford, Connecticut, USA \\ Email: ^Prashantsingh@ufl.edu, ahsancuet08@gmail.com
}

How to cite this paper: Singh, P., \& Islam, Md. A. (2020). Impact of Land Use Changes in Florida Mega Region: Study of FDOT (D-5) from Year 2007-2015. Current Urban Studies, 8, 365-380. https://doi.org/10.4236/cus.2020.83020

Received: July 3, 2020

Accepted: August 10, 2020

Published: August 13, 2020

Copyright $\odot 2020$ by author(s) and Scientific Research Publishing Inc. This work is licensed under the Creative Commons Attribution International License (CC BY 4.0).

http://creativecommons.org/licenses/by/4.0/

(c) (i) Open Access

\begin{abstract}
The main objective of the paper is to study the land use change in the District 5 of Florida mega region to see how land use is changing from year 2007, $2009,2010,2012,2014 \& 2015$. The study aims to look at the land use change from Agriculture open to development to various land attribute like residential, vacant residential, vacant nonresidential, industrial, institutional, ROW, Agriculture. The land use change study has become an important part of transportation planning initiative. The study uses land use data from university of Florida geo plan center for the year 2007, 2009, 2010, 2012, 2014 \& 2015. The data is obtained as raster files which will be converted to vector for each attribute of land use parcels. The comparative analysis of the data considering year 2009 as base year will be used and statistical analysis. The statistical analysis will be used to see if the land use change is significant in comparison to base year. The similar data set will be created to using the ten miles buffer for the interstate and 5 miles buffer for the state highway. The study will help understand the land use change pattern over the year and predict future change.
\end{abstract}

\section{Keywords}

Land Use, Planning, Agriculture, Residential,

Agriculture Open to Development

\section{Introduction and Motivation}

Over the past few decades, the urbanization has been done at unprecedented pace. Some of it is because of growth of population in the urban areas and others because of rapid growth and economic transformation in urban areas, allowing 
millions of people to migrate from rural agriculture areas to more productive activities.

Megaregions are network of metropolitan centers and their surrounding areas. They are spatially and functionally linked through environmental, economic and infrastructure interaction. Land use change plays a major role in transportation and urban planning. However, the change in land use results in growth pressure in urban-rural fringe. Therefore, a thorough analysis of land use change pattern and its ability to predict these changes are important for the sustainable growth (Carmen et al., 2009).

With the rise of Mega region as new economic unit. There is substantial change in the way policies are framed considering new trends in transportation and urban planning. There is substantial change in the way (Figure 1).

Labor and capital are reallocated by the economic process. In this new economic unit land use is of vital importance since the planning and policies are now not specific region of a city or county. However, this has been replaced by a major region encompassing wider area functionally interlinked.

To understand the land use change in the mega region. Of the various megaregions in United States FDOT district 5 of Florida mega region has been considered (Figure 2).

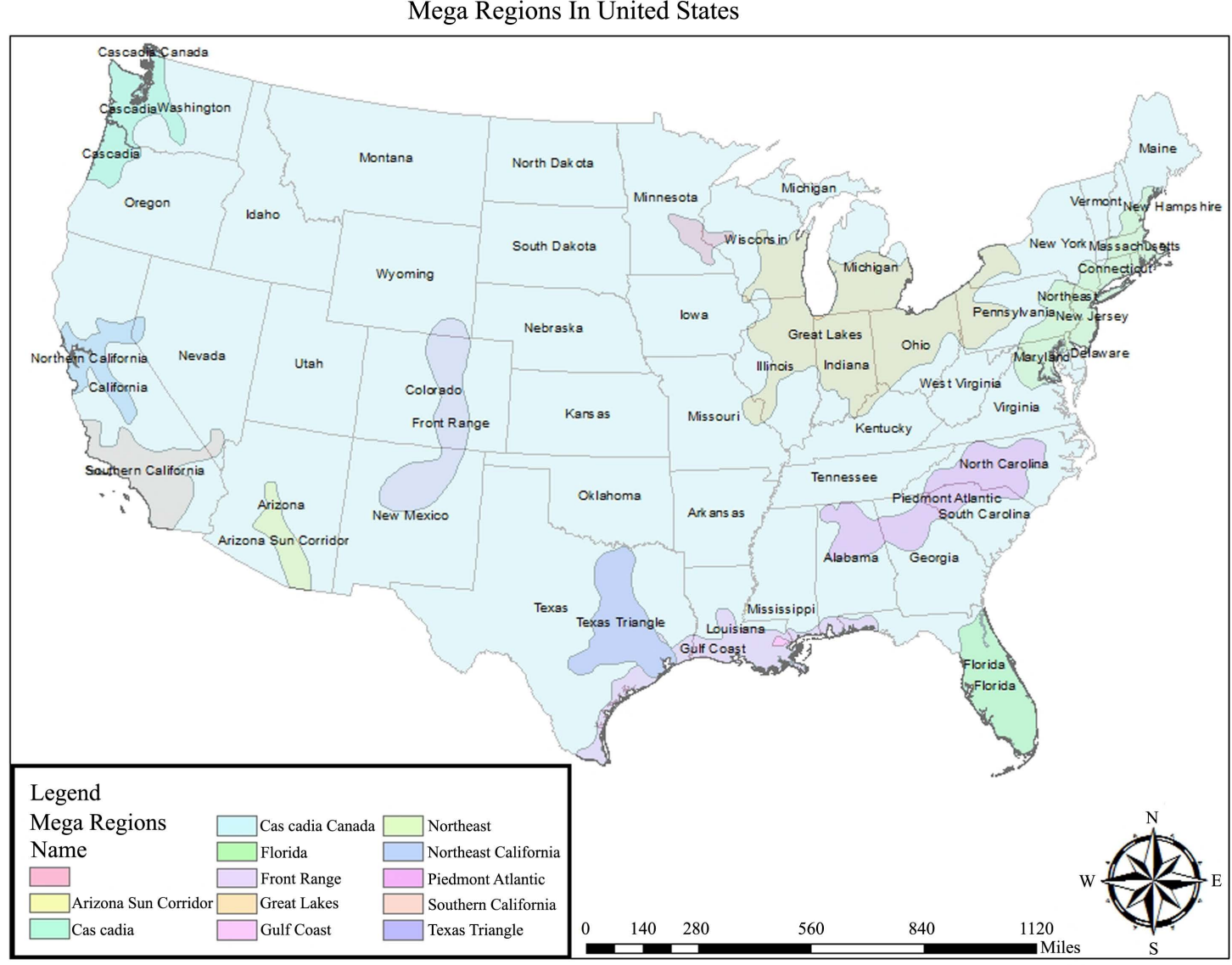

Figure 1. Mega regions in United States. 
Florida Mega Region-Study Area

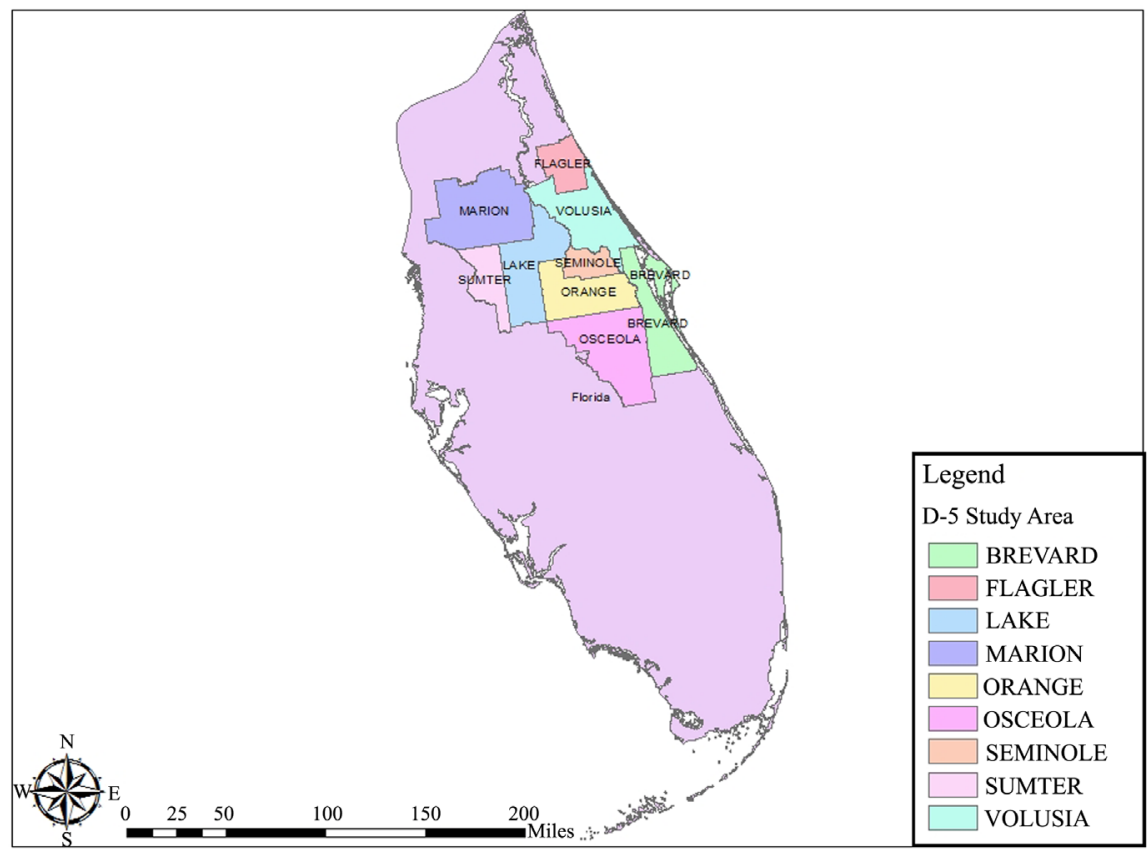

Figure 2. Florida mega region and D-5 study area.

The objectives of the research are listed below:

- To study the land use change pattern in FDOT (Florida Department of Transportation), District-5 (Part of Florida Mega region).

- To compare the land use change from one attribute to other for the year 2007, 2009, 2010, 2012, 2014, 2015 considering 2007 as the base year.

- Create different data set using the available attribute from the Land use data and conduct the statistical analysis to check if the land use change has been significant with base year or not. This model can be used to study the impact of land use change on various areas like population, road network, trip generation, transportation.

- The similar data set will be created for the parcels size within ten miles of interstate highway and within 5 miles of state highway. This analysis will be used to see if the land use change within interstate is more statistically significant or vice versa.

\section{Literature Review}

Land use change in past decades have led to increased conversion of rural land in many urban peripherals and exurban areas in US. The growth of the exurban area has outpaced the growth in urban and suburban areas, resulting in pressure on urban-rural fringe (Carmen et al., 2009). A multinomial discrete choice model with spatial dependence using parcels-level data from Medina County, Ohio was used. This model extends to binary choice "linearized logit model" of Klier and McMillen (2008). 
Land-use planning is usually a very local Function and there is a greater coordination and collaboration among many local governments provides an opportunity to tackle larger scale issues around land use and transportation. Similarly, collaborative area/regional planning involving multiple stakeholders can be used to overcome resistance to mixed-use, higher-density, and transit-oriented development.

Hui Ca et al. (2017), in their research "Urban Expansion and Its Impact on the Land Use Pattern in Xishuangbanna China", talks about how urban expansion and land use pattern are linked. The study predicts that Urbanization will affect land use change especially along the urban-rural gradients and lead to problems related to land use, such as land changed into discrete land uses, conversion from native to designed land cover or development into a non-contiguous or "leap frog" pattern. The study finds that these consequences could then affect the ecosystem and environment properties, including ecosystem services, biodiversity, biogeochemical cycles, climate conditions, etc. As an example, the rapid urbanization will contribute to the direct loss of agricultural land and increased agricultural land use intensity and, finally, affect food production. In the study of urban expansion, a radar graph is commonly used as an effective way to reflect the orientation characteristics of urban expansion by summarizing urban expansion indexes (like area or distance to urban center) in different directions (Hui Ca et al., 2017).

The study concluded that the city proper could further expand through either developing Gasa town southwest of the city proper or converting rubber between Jinghong Industrial Park and the downtown area into urban land. For the urban development of Xishuangbanna, no more rubber should be planted around urban areas. Rubber plantations also threaten natural forest and biodiversity and lead to soil and water degradation. Therefore, there is an urgent need for sustainable measures on rubber management and reforestation, such as eco-compensation mechanisms and ecological governance, combining science and indigenous knowledge. Land fragmentation is another problem that will make land management more difficult and increase conflicts between humans and wildlife. Urban planners and policy makers should find solutions to balance urban development and biodiversity conservation (Hui Ca et al., 2017).

According to Wu et al. (2010), substantial reduction in the arable land due to rapid urbanization has created threat to the food security and impact on availability of the land for the projects related to infrastructure. A system based dynamic method for assessing the urbanization land use change in policy with reference to practices in china has been introduced in this research. In implementing urbanization in China four typical policy scenarios identified are: 1) planning driven by balanced development; 2) planning driving uneven development; 3) uneven and balanced development driven by market and use of dynamic system model to analyze the impact of land use change. To assess the impact of four different land use changes urbanization policies in china the system dynamic method has been used. 
China's Jinyun County case study predicts that Scenario 1 or Scenario 2 of planning policies will lead to decreased agricultural land use, slight decrease in open land after 2010 and urban construction land areas slow growth. Scenario 3 or Scenario 4 of the market driven policies will boost urban construction land area until 2010 and decreased open and agricultural land afterwards. Study aim to help predict the likely consequences of their decisions by decision maker and policy implementation adjustment to be made. SD models, therefore, can be used as a decision-making tool and to monitor land use change for development of urbanization policy (Wu et al., 2010).

According to Bettinger and Merry (2019), there are 13 major land classes and their subclasses assessment of land occupied by them, estimates of the confidence interval developed, and rates of management activities annually were estimated. Increased commerce space of the southern landscape and human living observed was mainly at the expense of ecosystem covered of tree (generally exclusive of woodlands in Texas and Oklahoma), pastures and cropland areas. Only $1.5 \%$ of the represented south area in 2013 was developed. 1.6\% of the area represented for transportation. During study period one land use classes gained area from other land use classes.

The land use pattern and land cover in Florida has changed substantially since 1900. Population and tourism increase were coincident with the development which was facilitated by highway, railroad and marketing campaign focusing on visitors and new residents to come to state (Derr, 1998). Development of transportation network like interstate system like I-4, I-75, Florida turnpike, tourism in metropolitan region like Orlando has been the reason for the major land use change (Volk et al., 2017).

Land use change models are central for urban feature forecasting. Various land use change Binomial and multinomial logit model of various legged explanatory variables offers land dynamics insight. Various variables like parcel shape and size, slope, $\mathrm{CBD}$ access andtransit, distance to the nearest highway, and zoning policies, as well as each parcel's "neighborhood" attributes are recognized by these models. substantial predictive powers are offered by Neighborhood conditions however beyond 2 miles such efforts seem inconsequential (Zhou \& Kockelman, 2008).

According to Rodriguez et al. (2004), two phase study was developed. First phase was focused on conducting a literature review comprehensively on connection between land use and transportation. All the municipalities in the counties were selected in North Carolina and surveyed for the land use plan characteristics, their presence and adopted tools and policies for the management of land development as they relate to the transportation factors. The study examined planned investment for all the communities in the transportation area in the state of North Carolina for the period of 2004-2010. The second, phase of the study analyzed the content of land use plans selected from 30 local plans from communities used in the first phase of survey. A legal primer to be used by state 
and regional planners was developed to comprehend the potential inconsistencies and relationship between land use or comprehensive plans and zoning ordinances.

The survey result by planners and the content analysis of municipal plans of thirty counties selected randomly ensured that they are representative of the state and suggest that in spite of awareness regarding connection between land use and transportation issues, this connection is not visible in the land use plans. The results of both the studies suggested that land use plans implementation needs to be strengthened (Rodriguez et al., 2004).

According to Singh (2005) and Singh \& Spainhour (2004) around 25 percent of the crashes in the study set data is not traditional ROR crashes but were crashes where the vehicle ran off the roadway at a gentle angle, then attempted to oversteered back onto the roadway, resulting in a loss of control and a subsequent crash either with another vehicle, a fixed object on the same or opposite side of the road, or due to overturning because of loss of lateral stability. The study also suggests the relationship between land use and its effect on crashes.

Das \& Islam (2016), Hasan et al. (2016), Islam (2017, 2018, 2019), Singh \& Islam (2020) presumed that ROR crashes can be stopped in autonomous vehicles with the implementation of standardized protocol both during and after construction. There is impact on the movement of autonomous vehicles in work zone due to land use constraints. Use of autonomous vehicles can reduce the work zone land requirement specially when acquiring land for construction is expensive and challenging.

\section{Data Description}

The current research involves the FDOT-District- 5 as area of study in the Florida Mega regions. For the said research GIS data base for the land use plans for years 2007, 2009, 2010, 2012, 2014 and 2015 were procured as raster images from FGDL open source data. The available data has been created for FDOT, District-5 with total nine counties listed as, Marion, Volusia, Flagler, Sumter, Lake, Seminole, Orange, Brevard and Osceola. The initial data set had ninety-nine land use type which were classified in to fifteen categories. The land use data has been cleaned up for total sixteen attributes. These attributes are Agriculture, Agriculture open to development, Operating railroad property, Industrial, Institutional, Mining, No values available, others, Public/Semipublic, recreation, residential, retail/office, ROW, vacant residential, vacant nonresidential and water.

Since the data contained all these attributes in one raster image for each individual year. The first major step was the segregation of the each individual attribute data from each year raster image. Arc map was used as a tool to convert the raster image file in to shape files. Shape files of each year data was sorted by using command select by attribute feature, and individual shape files for each attribute was created. For extracting the data needed for the research 2007 was 
considered as the base year attributes like Agriculture, Agriculture open to development, vacant residential, vacant nonresidential were compared with selected attributes like residential, public/semipublic, retail/offices, Industrial, Institutional, ROW for year 2009, 2010, 2012, 2014 and 2015. The data showed the change in land use pattern each year from one attribute to other (Figure 3 and Figure 4).

\section{Modeling Methodology}

The main goal of the study is to understand the land use change based on various choices. The decision of parcel from one land use type to other depends on various factors such as type of land needed based on its end use, its accessibility to major road network, size of parcels, proximity of parcels from urban centers or central business district if close to city limits, population. The available land data shows that there are land use with agriculture open to development which can be converted to residential, retail/office, industrial, institutional based on the probable choices made by the developer.

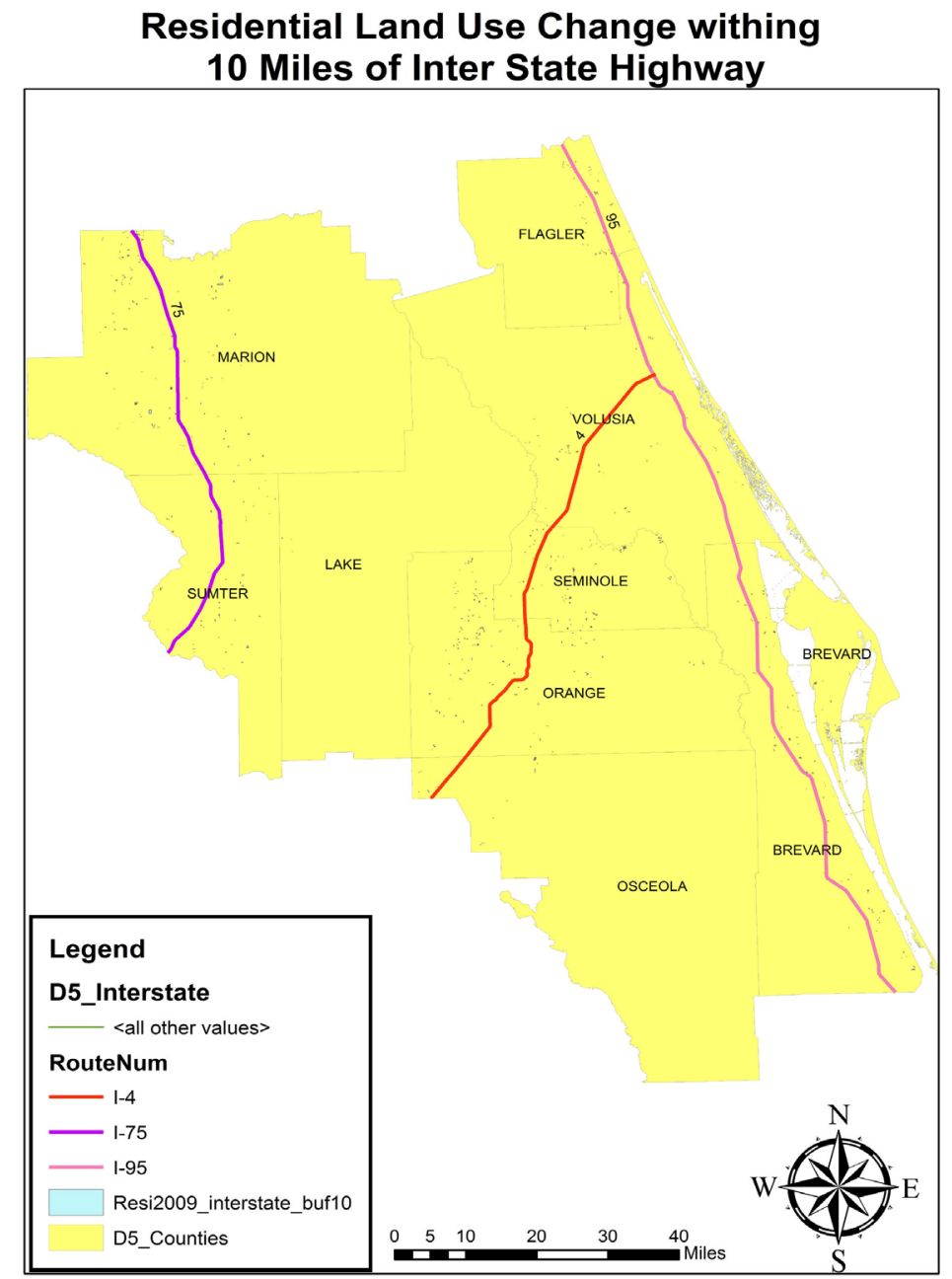

Figure 3. Residential parcels within 10 miles of interstate highway. 


\section{Residential Land Use Change withing 5 Miles of State Highway}

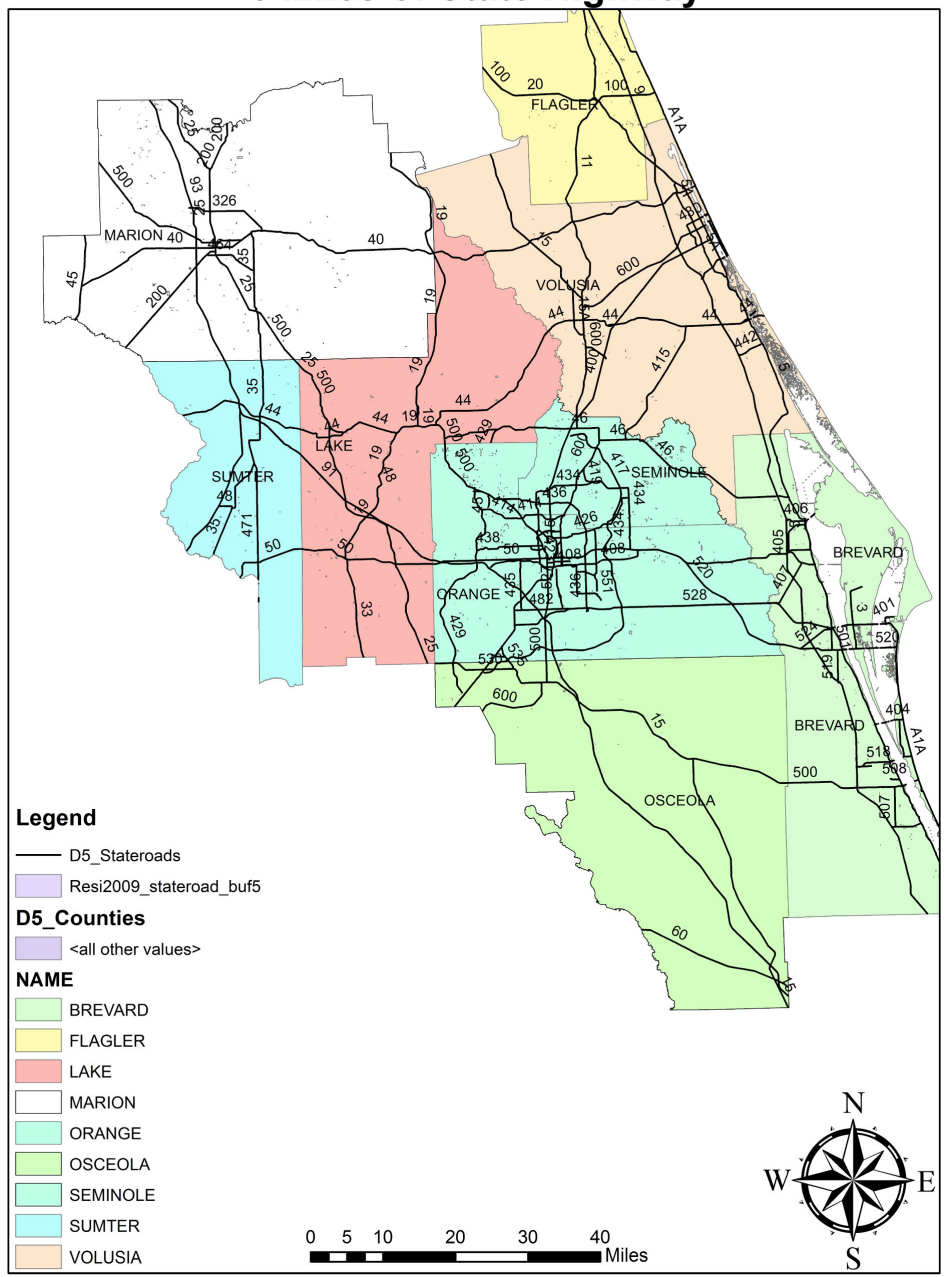

Figure 4. Residential land use change within 5 miles of state highway.

The intension of this research is to figure out the relationship between land use change and various factors associated with land use change. Statistical t test will be done between the data of year like 2009-2010, 2009-2012, 2009-2014, and 2009-2015. If the " $\mathrm{t}$ " stats is more than "tcritical" then the land use change is significant.

\section{Analysis and Results}

Data analysis is done for year 2007, 2009, 2010, 2012, 2014 and 2015 land use data. The data is available in the form of parcels. For the analysis total thirteen attributes have been considered. Table 1 shown that there is a decrease in the available land in agriculture from year 2007 to 2015. But for Agriculture open to development there is substantial decrease of $33 \%$ from 2007 to 2015.

Table 2 shown various land use change considering year 2007 as base year. In this study land use change from Agriculture open to development to agriculture, Industrial, Institutional, vacant residential has been considered to analyze the 
Table 1. Land use area.

\begin{tabular}{|c|c|c|c|c|c|c|}
\hline \multirow{3}{*}{ Land Use Type } & \multicolumn{6}{|c|}{ Area (Acres) } \\
\hline & \multicolumn{6}{|c|}{ Year } \\
\hline & 2007 & 2009 & 2010 & 2012 & 2014 & 2015 \\
\hline Agriculture & $2,137,887.68$ & $2,159,090.74$ & $2,143,516.19$ & $2,161,182.62$ & $2,123,187.66$ & $2,106,971.71$ \\
\hline Ag. Open to Development & $233,915.85$ & $209,723.86$ & $219,209.71$ & $206,387.53$ & $178,873.31$ & $174,954.26$ \\
\hline Mining & 2232.35 & 3350.38 & 2440.74 & 3646.59 & $10,374.46$ & $174,954.26$ \\
\hline Residential & $643,063.00$ & $641,702.15$ & $645,062.00$ & $641,814.02$ & $660,042.13$ & $717,730.82$ \\
\hline Vacant Residential & $326,388.87$ & $315,361.58$ & $302,847.00$ & $302,245.22$ & $315,888.77$ & $281,168.01$ \\
\hline Vacant Non residential & $69,861.17$ & $68,295.79$ & $66,561.21$ & $67,317.57$ & $68,610.47$ & $70,365.24$ \\
\hline No Value Available & $335,198.86$ & $195,341.74$ & $514,796.83$ & $68,342.17$ & $121,672.24$ & $112,179.20$ \\
\hline Public/Semipublic & $1,238,118.54$ & $1,265,945.42$ & $1,220,308.57$ & $1,299,319.00$ & $1,569,207.59$ & $1,588,463.37$ \\
\hline Others & $35,536.32$ & $35,231.65$ & $37,481.44$ & $36,026.08$ & $33,296.97$ & $32,201.01$ \\
\hline Retail/office & $77,923.25$ & $83,974.04$ & $84,380.30$ & $83,253.44$ & $85,476.17$ & $86,665.28$ \\
\hline Industrial & $31,821.15$ & $33,304.89$ & $33,128.03$ & $32,913.46$ & $33,848.57$ & $34,398.57$ \\
\hline Institutional & $34,522.76$ & $32,882.88$ & $33,128.03$ & $34,115.85$ & $35,922.39$ & $34,437.36$ \\
\hline ROW & 7743.72 & 8289.63 & 7063.93 & 9088.82 & $10,166.16$ & 8866.92 \\
\hline
\end{tabular}

land use change with respect to year 2009, 2010, 2012, 2014 and 2015. The results show that land use change from agriculture open to development from year 2009 to 2015 changes from modest $1 \%$ to $5.17 \%$. Similarly vacant residential also has land use change from $1.08 \%$ in 2009 to $11.28 \%$ in 2015. Land use change for public/semipublic also shows the similar results. On the contrary land use change from agriculture open to development to agriculture decreases from $18.04 \%$ in 2009 to $8.14 \%$ in 2015 . The results for other attributes are not varying much from year 2009 to 2015 .

The results justifies as year 2008-2009 was the period of economic slowdown and during this period there has been very slow growth rate in residential and commercial area but, this has picked up around 2015. During this period land use change to agriculture was very high and reduced as the economic growth picked up around 2015. The results can also be verified from Table 3 which shows that the land use change was significant during this period.

Table 3 below shows the statistical analysis of land use change from Agriculture open to development to land use attributes of residential, agriculture, vacant residential, residential, Industrial, Institution, ROW, Public/Semipublic, retail/offices. The statistical analysis justifies the results shown in Table 2.

Table 4 and Table 5 gives the statistical analysis of land use change within ten miles of interstate highway. Table 5 shows that percentage land use change with respect to actual land use change area.

The results in Table 6 and Table 7 shows that land use change within 5 miles of state highway is more consistent and significant then within ten miles of interstate highway. 
Table 2. Land use change with 2007 as base year.

\begin{tabular}{|c|c|c|c|c|c|c|c|}
\hline & $\begin{array}{c}\text { Base Year Land } \\
\text { Use and Area } \\
\text { (Acres) }\end{array}$ & $\begin{array}{c}\text { Land Use } \\
\text { Change and } \\
\text { Area (Acres) }\end{array}$ & & & & & \\
\hline S. No. & 2007 & & 2015 & 2014 & 2012 & 2010 & 2009 \\
\hline \multirow[t]{19}{*}{1} & $\begin{array}{l}\text { Agriculture } \\
\text { open to } \\
\text { Development }\end{array}$ & & $\begin{array}{c}\text { Land Use } \\
\text { Change } \\
\text { Area }\end{array}$ & $\begin{array}{c}\text { Land Use } \\
\text { Change } \\
\text { Area }\end{array}$ & $\begin{array}{c}\text { Land Use } \\
\text { Change } \\
\text { Area }\end{array}$ & $\begin{array}{c}\text { Land Use } \\
\text { Change } \\
\text { Area }\end{array}$ & $\begin{array}{c}\text { Land Use } \\
\text { Change } \\
\text { Area }\end{array}$ \\
\hline & $233,915.85$ & Residential & $12,097.60$ & 9535.92 & 4532.20 & 3662.06 & 2334.33 \\
\hline & & $\%$ & 5.17 & 4.08 & 1.94 & 1.57 & 1.00 \\
\hline & & Agriculture & $19,041.10$ & $26,503.59$ & $34,754.24$ & $40,520.20$ & $42,194.53$ \\
\hline & & $\%$ & 8.14 & 11.33 & 14.86 & 17.32 & 18.04 \\
\hline & & $\begin{array}{c}\text { Vacant } \\
\text { Residential }\end{array}$ & $26,382.16$ & $27,430.46$ & 6114.74 & 4520.63 & 2520.27 \\
\hline & & $\%$ & 11.28 & 11.73 & 2.61 & 1.93 & 1.08 \\
\hline & & $\begin{array}{c}\text { Vacant } \\
\text { Non-residential }\end{array}$ & 5497.84 & 4907.60 & 2860.97 & 2571.42 & 1949.36 \\
\hline & & $\%$ & 2.35 & 2.10 & 1.22 & 1.10 & 0.83 \\
\hline & & $\begin{array}{c}\text { Public/ } \\
\text { Semipublic }\end{array}$ & $30,683.00$ & $26,842.01$ & $13,124.52$ & 7469.53 & 6012.34 \\
\hline & & $\%$ & 13.12 & 11.48 & 5.61 & 3.19 & 2.57 \\
\hline & & Retail/Offices & 963.79 & 699.41 & 327.83 & 357.54 & 291.47 \\
\hline & & $\%$ & 0.41 & 0.30 & 0.14 & 0.15 & 0.12 \\
\hline & & Industrial & 899.84 & 926.08 & 766.18 & 703.86 & 850.98 \\
\hline & & $\%$ & 0.38 & 0.40 & 0.33 & 0.30 & 0.36 \\
\hline & & Institutional & 1323.92 & 1284.49 & 842.73 & 412.05 & 295.36 \\
\hline & & $\%$ & 0.57 & 0.55 & 0.36 & 0.18 & 0.13 \\
\hline & & ROW & 409.39 & 362.52 & 248.46 & 182.72 & 323.61 \\
\hline & & $\%$ & 0.18 & 0.15 & 0.11 & 0.08 & 0.14 \\
\hline
\end{tabular}

Table 3. Land use change comparative statistical analysis.

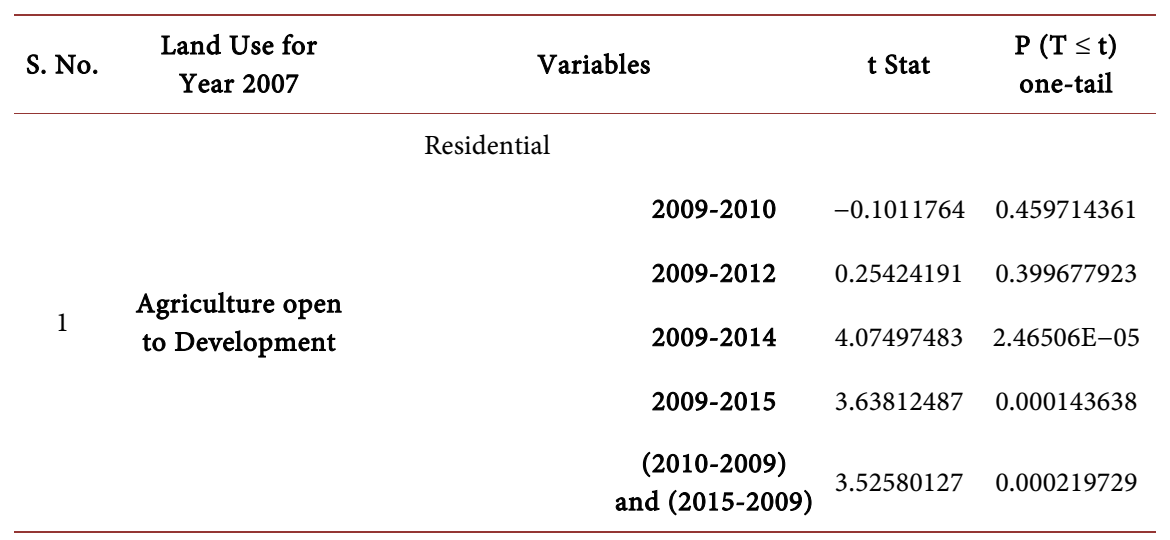




\section{Continued}

Agriculture open to Development

Agriculture open to Development

Agriculture open to Development

5

Agriculture open to Development

Agriculture open to Development
Agriculture

$\begin{array}{ccc}2009-2010 & 0.67986146 & 0.248402116 \\ 2009-2012 & 0.57559911 & 0.282530351 \\ 2009-2014 & 2.63488885 & 0.004296047 \\ 2009-2015 & 2.66936219 & 0.003882851 \\ \begin{array}{c}(2010-2009) \\ \text { and (2015-2009) }\end{array} & 2.01862992 & 0.021942482\end{array}$

Vacant Residential

$\begin{array}{ccc}2009-2010 & 0.2354445 & 0.406969536 \\ 2009-2012 & 0.65159699 & 0.257447549 \\ 2009-2014 & 2.70934092 & 0.00346108 \\ & & \\ 2009-2015 & 1.66782652 & 0.047919668 \\ \begin{array}{c}(2010-2009) \\ \text { and (2015-2009) }\end{array} & 1.58017813 & 0.057280073\end{array}$

Vacant

Non-residential

$\begin{array}{ccc}\mathbf{2 0 0 9 - 2 0 1 0} & 1.10513891 & 0.135349298 \\ \mathbf{2 0 0 9 - 2 0 1 2} & 1.55284008 & 0.061182895 \\ \mathbf{2 0 0 9 - 2 0 1 4} & 0.12337882 & 0.450978192 \\ \mathbf{2 0 0 9 - 2 0 1 5} & 1.67147336 & 0.048256133 \\ \begin{array}{c}(\mathbf{2 0 1 0 - 2 0 0 9 )} \\ \text { and (2015-2009) }\end{array} & 0.84618007 & 0.199335219\end{array}$

Public/Semipublic

\begin{tabular}{|c|c|c|}
\hline 2009-2010 & 0.27613266 & 0.391304113 \\
\hline $2009-2012$ & 0.34020288 & 0.366953337 \\
\hline 2009-2014 & 1.58484459 & 0.056949797 \\
\hline 2009-2015 & 1.58484459 & 0.056949797 \\
\hline 2010-2009) & 1.33839557 & 0.090815684 \\
\hline
\end{tabular}

Retail/Offices

$\begin{array}{rrr}\mathbf{2 0 0 9 - 2 0 1 0} & 0.8806665 & 0.190315651 \\ 2009-2012 & 1.39472159 & 0.083110718 \\ 2009-2014 & 2.19047303 & 0.015418521 \\ & & \\ 2009-2015 & 2.25362868 & 0.013212362 \\ \begin{array}{c}(2010-2009) \\ \text { and (2015-2009) }\end{array} & 1.71455809 & 0.0447776 \\ & & \\ & & \\ \mathbf{2 0 0 9 - 2 0 1 0} & 1.54447781 & 0.065733694\end{array}$




\section{Continued}

\begin{tabular}{|c|c|c|c|c|c|}
\hline & & & 2009-2012 & 1.37472126 & 0.088977931 \\
\hline & & & 2009-2014 & 1.54542628 & 0.065619113 \\
\hline & & & 2009-2015 & 1.54113864 & 0.066138373 \\
\hline & & & $(2010-2009)$ & & \\
\hline & & & and (2015-2009) & 0.19864783 & 0.421843834 \\
\hline \multirow{7}{*}{8} & \multirow{7}{*}{$\begin{array}{l}\text { Agriculture open } \\
\text { to Development }\end{array}$} & Institutional & & & \\
\hline & & & 2009-2010 & -0.1972147 & 0.422384383 \\
\hline & & & 2009-2012 & -0.0439591 & 0.482589967 \\
\hline & & & 2009-2014 & 1.18120845 & 0.122632417 \\
\hline & & & $2009-2015$ & 1.18165985 & 0.122543939 \\
\hline & & & $(2010-2009)$ & 147436565 & 0074537583 \\
\hline & & & and (2015-2009) & $1.4 / 436565$ & $0.0 / 453 / 583$ \\
\hline \multirow{7}{*}{9} & \multirow{7}{*}{\multicolumn{2}{|c|}{$\begin{array}{l}\text { Agriculture open } \\
\text { to Development }\end{array}$}} & & & \\
\hline & & & 2009-2010 & 0.88253363 & 0.189791984 \\
\hline & & & 2009-2012 & 0.95515713 & 0.170889402 \\
\hline & & & $2009-2014$ & 2.18604906 & 0.015560897 \\
\hline & & & 2009-2015 & 2.18738873 & 0.015510515 \\
\hline & & & $(2010-2009)$ & 155119428 & 0061991542 \\
\hline & & & and (2015-2009) & & \\
\hline
\end{tabular}

Table 4. Land use change within 10 miles of interstate highway-comparative statistical analysis.

\begin{tabular}{|c|c|c|c|c|c|}
\hline S. No. & $\begin{array}{c}\text { Land Use } \\
\text { For Year } 2007\end{array}$ & Variable & & t Stat & $\begin{array}{l}P(T \leq t) \\
\text { one-tail }\end{array}$ \\
\hline \multirow[t]{5}{*}{1} & & Residential & & & \\
\hline & & & 2009-2010 & -0.693098071 & 0.244236224 \\
\hline & & & 2009-2012 & -1.028407903 & 0.152052396 \\
\hline & & & 2009-2014 & -1.028407903 & 0.152052396 \\
\hline & & & $2009-2015$ & 2.387016323 & 0.008621979 \\
\hline \multirow[t]{5}{*}{3} & & Vacant Residential & & & \\
\hline & & & $2009-2010$ & -0.020833166 & 0.491693897 \\
\hline & Agriculture open & & 2009-2012 & -0.016335119 & 0.493487069 \\
\hline & to Development & & 2009-2014 & 1.577113737 & 0.057729138 \\
\hline & & & $2009-2015$ & 0.915153075 & 0.180295895 \\
\hline \multirow[t]{6}{*}{4} & & Vacant & & & \\
\hline & & Non-residential & & & \\
\hline & & & $2009-2010$ & 1.255948108 & 0.105620867 \\
\hline & & & 2009-2012 & 1.425218531 & 0.078167825 \\
\hline & & & 2009-2014 & 0.220436605 & 0.412927291 \\
\hline & & & 2009-2015 & 2.150758435 & 0.016612345 \\
\hline
\end{tabular}




\section{Continued}

\begin{tabular}{|c|c|c|c|c|}
\hline \multirow[t]{5}{*}{5} & Retail/Offices & & & \\
\hline & & 2009-2010 & 0.735762545 & 0.23197471 \\
\hline & & $2009-2012$ & 1.241203929 & 0.10901348 \\
\hline & & 2009-2014 & 1.857701121 & 0.033378789 \\
\hline & & $2009-2015$ & 1.925779255 & 0.028777953 \\
\hline \multirow[t]{5}{*}{6} & Industrial & & & \\
\hline & & 2009-2010 & 1.325491486 & 0.099304483 \\
\hline & & 2009-2012 & 1.370579552 & 0.092164647 \\
\hline & & 2009-2014 & 1.46459391 & 0.078588323 \\
\hline & & $2009-2015$ & 1.451142926 & 0.080425463 \\
\hline \multirow[t]{2}{*}{7} & ROW & & & \\
\hline & & $2009-2015$ & 0.437606534 & 0.331648409 \\
\hline
\end{tabular}

Table 5. Percentage land use change within 10 miles of interstate highway.

\begin{tabular}{|c|c|c|c|c|c|c|}
\hline S. No. & Land Use & 2009 & 2010 & 2012 & 2014 & 2015 \\
\hline & Residential & 1203.644 & 2385.15 & 2925.89 & 2925.9 & 8015.2 \\
\hline \multirow[t]{3}{*}{1} & Actual Residential Area & 2334.332 & 3662.06 & 4532.2 & 9535.9 & 12098 \\
\hline & $\%$ of Actual residential Area & 51.56267 & 65.1313 & 64.5579 & 30.683 & 66.255 \\
\hline & Vacant Residential & 1582.164 & 2800.87 & 3925.52 & 15748 & 15081 \\
\hline \multirow[t]{3}{*}{2} & Actual Vacant Residential Area & 2520.274 & 4520.63 & 6114.74 & 27430 & 26382 \\
\hline & $\%$ of actual vacant residential area & 62.77748 & 61.9574 & 64.1976 & 57.412 & 57.163 \\
\hline & Vacant Non Residential & 1720.816 & 2092.54 & 2335.72 & 4027.6 & 4592.4 \\
\hline \multirow[t]{3}{*}{3} & Actual Vacant Non Residential Area & 1949.361 & 2571.42 & 2860.97 & 4907.6 & 5497.8 \\
\hline & $\%$ of Actual vacant Nonresidential area & 88.2759 & 81.3768 & 81.6409 & 82.069 & 83.531 \\
\hline & Retail/Offices & 249.8471 & 314.371 & 273.951 & 480.64 & 735.01 \\
\hline \multirow[t]{3}{*}{4} & Actual Retail/Offices Area & 291.4667 & 357.543 & 327.831 & 699.41 & 963.79 \\
\hline & $\%$ of Actual Retail/office Area & 85.72061 & 87.9255 & 83.5646 & 68.721 & 76.262 \\
\hline & Industrial & 788.20295 & 640.6433 & 694.2306 & 731.445 & 681.34 \\
\hline \multirow[t]{3}{*}{5} & Actual Industrial Area & 850.9849 & 703.863 & 766.182 & 926.08 & 899.84 \\
\hline & $\%$ of Actual Industrial Area & 92.62243 & 91.0182 & 90.6091 & 78.983 & 75.718 \\
\hline & ROW & 162.62477 & 5.916976 & 6.998351 & 18.8919 & 116.09 \\
\hline \multirow[t]{2}{*}{6} & Actual ROW Area & 323.6064 & 182.72 & 248.46 & 362.52 & 409.39 \\
\hline & $\%$ of Actual ROW & 50.25387 & 3.23828 & 2.81669 & 5.2113 & 28.357 \\
\hline
\end{tabular}

Table 6. Land use change within 5 miles of state highway-comparative statistical analysis.

\begin{tabular}{cccccc}
\hline S. No. & $\begin{array}{c}\text { Land Use } \\
\text { For Year 2007 }\end{array}$ & Variables & t Stat & $\begin{array}{c}\mathbf{P}(\mathrm{T} \leq \mathrm{t}) \\
\text { one-tail }\end{array}$ \\
\hline & Agriculture & Residential & & & \\
open to & & $2009-2010$ & -0.061901647 & 0.475326413 \\
& Development & $2009-2012$ & 0.442606108 & 0.329070483 \\
\hline
\end{tabular}




\section{Continued}

\begin{tabular}{|c|c|c|c|c|}
\hline & & 2009-2014 & 3.780920046 & $8.24858 \mathrm{E}-05$ \\
\hline & & 2009-2015 & 3.396026469 & 0.000354539 \\
\hline \multirow[t]{5}{*}{3} & Vacant Residential & & & \\
\hline & & $2009-2010$ & -0.266414442 & 0.395003677 \\
\hline & & 2009-2012 & 0.392459204 & 0.34742595 \\
\hline & & 2009-2014 & 2.097517933 & 0.018173132 \\
\hline & & $2009-2015$ & 1.261059764 & 0.103877419 \\
\hline \multirow[t]{5}{*}{4} & Vacant Non-residential & & & \\
\hline & & $2009-2010$ & 1.114619728 & 0.133317152 \\
\hline & & $2009-2012$ & 1.474349289 & 0.071146491 \\
\hline & & 2009-2014 & 0.121204409 & 0.451838304 \\
\hline & & 2009-2015 & 1.643016772 & 0.051141878 \\
\hline \multirow[t]{5}{*}{5} & Retail/Offices & & & \\
\hline & & $2009-2010$ & 0.881889331 & 0.189997298 \\
\hline & & 2009-2012 & 1.359673281 & 0.088526739 \\
\hline & & 2009-2014 & 2.195959179 & 0.015226923 \\
\hline & & 2009-2015 & 2.259657527 & 0.013028313 \\
\hline \multirow[t]{5}{*}{6} & Industrial & & & \\
\hline & & 2009-2010 & 1.546446945 & 0.065767043 \\
\hline & & 2009-2012 & 1.375926285 & 0.089055704 \\
\hline & & 2009-2014 & 1.532698942 & 0.067441008 \\
\hline & & 2009-2015 & 1.527708202 & 0.06805714 \\
\hline \multirow[t]{2}{*}{7} & ROW & & & \\
\hline & & 2009-2015 & 0.941977835 & 0.17461417 \\
\hline
\end{tabular}

Table 7. Percentage land use change within 5 miles of interstate highway.

\begin{tabular}{|c|c|c|c|c|c|c|}
\hline & & 2009 & 2010 & 2012 & 2014 & 2015 \\
\hline \multirow{3}{*}{1} & Residential & 2169.006 & 3438.74 & 4159.22 & 9013.2 & 11,450 \\
\hline & Actual Residential Area & 2334.332 & 3662.06 & 4532.2 & 9535.9 & 12,098 \\
\hline & $\%$ of Actual residential Area & 92.9176 & 93.9019 & 91.7704 & 94.518 & 94.646 \\
\hline \multirow{3}{*}{2} & Vacant Residential & 2502.551 & 4418.26 & 5993 & 27077 & 26015 \\
\hline & Actual Vacant Residential Area & 2520.274 & 4520.63 & 6114.74 & 27430 & 26382 \\
\hline & $\%$ of actual vacant residential area & 99.2968 & 97.7355 & 98.0091 & 98.712 & 98.609 \\
\hline \multirow{3}{*}{3} & Vacant Non Residential & 1949.042 & 2562.89 & 2852.57 & 4899 & 5487.7 \\
\hline & Actual Vacant Non Residential Area & 1949.361 & 2571.42 & 2860.97 & 4907.6 & 5497.8 \\
\hline & $\%$ of Actual vacant Nonresidential area & 99.98365 & 99.6684 & 99.7064 & 99.825 & 99.815 \\
\hline \multirow{3}{*}{4} & Retail/Offices & 291.4112 & 357.487 & 327.775 & 698.94 & 961.89 \\
\hline & Actual Retail/Offices Area & 291.4667 & 357.543 & 327.831 & 699.41 & 963.79 \\
\hline & $\%$ of Actual Retail/office Area & 99.98093 & 99.9845 & 99.983 & 99.932 & 99.803 \\
\hline \multirow{3}{*}{5} & Industrial & 842.66899 & 695.6273 & 757.9276 & 921.663 & 895.22 \\
\hline & Actual Industrial Area & 850.9849 & 703.863 & 766.182 & 926.08 & 899.84 \\
\hline & $\%$ of Actual Industrial Area & 99.02279 & 98.8299 & 98.9226 & 99.523 & 99.486 \\
\hline \multirow{3}{*}{6} & ROW & 307.95769 & 148.066 & 190.4273 & 253.702 & 281.58 \\
\hline & Actual ROW Area & 323.6064 & 182.72 & 248.46 & 362.52 & 409.39 \\
\hline & $\%$ of Actual ROW & 95.16427 & 81.0346 & 76.6431 & 69.983 & 68.781 \\
\hline
\end{tabular}




\section{Conclusion}

The land use change from year 2007 to 2015 shows the economic growth during this period and shows that land use change is more significant within ten miles of interstate highway than within five miles of state highway. The land use change study is a valuable direction for the modeling of land use intensity, population, employment. Land use change study plays an important part in policy making, planning and other legislation.

\section{Acknowledgements}

Theauthors express sincere gratitude to Dr. Siva Srinivasan, Associate Professor, Department of Civil and Coastal Engineering, the University of Florida for motivation and support in developing the concept.

\section{Conflicts of Interest}

The authors declare no conflicts of interest regarding the publication of this paper.

\section{References}

Bettinger, P., \& Merry, K. (2019). Land Cover Transition in the United States South: 2007-2013. Applied Geography, 105, 102-110. https://doi.org/10.1016/j.apgeog.2019.03.002

Ca, H., Liu, J., Fu, C., Zhang, W. F., Wang, G. Z., Yang, G., \& Luo, L. (2017). Urban Expansion and Its Impact on the Land Use Pattern in Xishuangbanna since the Reform and Opening up of China. Remote Sensing, 9, 137.

Carmen, E., Flores-Lagunes, A., \& Ledia, G. (2009). Land Use Change: A Spatial Multinomial Choice Analysis.

Das, A., \& Islam, M. A. (2016). Cylindrical Wedge-Type Compression Free Bracing System for Moment Resisting Frame Structures. In 3rd International Conference on Advances in Civil Engineering (pp. 441-446). Chittagong: ICNACE Secretariat.

Derr, M. (1998). Some Kind of Paradise: A Chronicle of Man and the Land in Florida. Gainesville, FL: University Press of Florida.

Hasan, M. A., Islam, M. A., Ahmed, Z., \& Ahmad, I. (2016). Compressive Strength Behavior of Concrete Using Rice Husk Ash as Supplementary to Cement. In 3rd International Conference on Advances in Civil Engineering (pp. 327-336). Chittagong: ICNACE Secretariat.

Islam, M. A. (2017). Requirements and Challenges Associated with Deployment of Connected Vehicles. Imperial Journal of Interdisciplinary Research, 3, 720.

Islam, M. A. (2018). Intergrading Connected Vehicle Data into the Transportation Performance Measurement Process. Doctoral Dissertation, Birmingham: The University of Alabama.

Islam, M. A. (2019). A Literature Review on Freeway Traffic Incidents and Their Impact on Traffic Operations. Journal of Transportation Technologies, 9, 504-516. https://doi.org/10.4236/jtts.2019.94032

Klier, T., \& McMillen, D. P. (2008). Clustering of Auto Supplier Plants in the United 
States: Generalized Method of Moments Spatial Logit for Large Samples. Journal of Business Economics and Statistics, 26, 460-471. https://doi.org/10.1198/073500107000000188

Rodriguez, D. A., Godschalk, D. R., \& Norton, R. K. (2004). Connection between Land Use and Transportation in Land Use Plans. Final Report, Raleigh, NC: North Carolina Department of Transportation.

Singh, P. (2005). A Study of Fatal Run off Road Crashes in the State of Florida. FSU-MS Thesis 2005.

Singh, P., \& Islam, M. A. (2020). Movement of Autonomous Vehicles in Work Zone Using New Pavement Marking: A New Approach. Journal of Transportation Technologies, 10, 183-197. https://doi.org/10.4236/jtts.2020.103012

Singh, P., \& Spainhour, L. (2004). Safety Analysis of Fatal Crashes Involving High Speed Vehicles. Nashville, TN: International Traffic Record Forum.

https://2004.trafficrecordsforum.org/Sessions/Wednesday 2536/S36/s36 trf_paper_sin gh and spainhour.pdf

Volk, M. I., Hoctor, T. S., Nettles, B. B., Hilsenbeck, R., Putz, F. E., \& Oetting, J. (2017). Florida Land Use and Land Cover Change in the Past 100 Years. In E. P. Chassignet, J. W. Jones, V. Misra, \& J. Obeysekera (Eds.), Florida's Climate: Changes, Variations, \& Impacts (pp. 51-82). Gainesville, FL: Florida Climate Institute.

Wu, Y. Z., Zhang, X. L., \& Shen, L. Y. (2010). The Impact of Urbanization Policy on Land Use Change: A Scenario Analysis. Cities, 28, 147-159.

Zhou, B., \& Kockelman, K. (2008). Neighbourhood Impacts on Land Use Change: A Multinomial Logit Model of Spatial Relationship. The Annals of Regional Science, 42, 321-340. 